\title{
LEAF QUALITY AND YIELD OF Gliricidia sepium (Jacq) Steud UNDER DIFFERENT POPULATION DENSITY AND CUTTING INTERVAL IN COCONUT PLANTATION
}

\author{
S. D. Anis ${ }^{1}$, D. A. Kaligis ${ }^{1}$, B. Tulung ${ }^{1}{\text { and } \text { Aryanto }^{2}}^{2}$ \\ ${ }^{1}$ Faculty of Animal Husbandry, Sam Ratulangi University, \\ Kampus UNSRAT Manado 95115 - Indonesia \\ ${ }^{2}$ Asassement Institute Agricultural Technology (AIAT) of North Sulawesi, \\ Jln. Kampus Pertanian Kalasey Satu. Kotak Pos 1345, Minahasa 95013 - Indonesia \\ CorespondingE-mail: selvie.anis@yahoo.com
}

Received May 18, 2015; Accepted March 04, 2016

\begin{abstract}
ABSTRAK
Tujuan penelitian ini adalah mengevaluasi kualitas daun dan pertumbuhan vegetatif Gliricidia sepium (Jacq) Steud pada kepadatan dan interval pemotongan yang berbeda di bawah pohon kelapa. Stek batang sepanjang $30 \mathrm{~cm}$ dengan diameter $2-3 \mathrm{~cm}$ ditanam dalam poly-bag berukuran $15 \times 25 \mathrm{~cm}$. Pemupukan Triple Super Phosphate (TSP) dan Kalium Cloride $(\mathrm{KCl})$ diberikan pada lahan percobaan sebanyak $75 \mathrm{~kg} / \mathrm{ha}$ saat pengolahan tanah dan pemberian pupuk urea $(\mathrm{N}) 100 \mathrm{~kg} / \mathrm{ha}$ saat tumbuhan berumur dua bulan. Perlakuan yang diuji kepadatan populasi tanaman Gliricidia sepium (Jacq) Steud dari 20,30, dan 40 tanaman per petak $9 \mathrm{~m}^{2}$ dikombinasikan dengan interval pemotongan pada setiap 3 , 6, 9 dan 12 minggu. Perlakuan diatur secara faktorial dalam rancangan acak kelompok. Variabel yang diamati adalah kualitas daun, produksi bahan kering dan pertumbuhan vegetatif. Hasil penelitian menunjukkan kandungan nutrien daun Gliricidia sepium (Jacq) Steud ditentukan oleh interval pemotongan, sedangkan performance vegetatif dipengaruhi oleh interaksi kepadatan tanaman dan interval pemotongan. Kesimpulan penelitian ini kualitas dan produksi legume pohon Gliricidia sepium (Jacq) Steud yang tinggi di bawah tegakan kelapa ditentukan oleh manajemen penanaman dan defoliasi.

Kata Kunci: Gliricidia, kualitas, kelapa, kepadatan, pemotongan.
\end{abstract}

\begin{abstract}
The objective of this study was to evaluate leaf quality of Gliricidia sepium (Jacq) Steud and vegetative growth under different population density and cutting interval in coconut plantation. Plant material of $30 \mathrm{~cm}$ length with diameter of 2-3 cm were planted in the poly-bag of $15 \times 25 \mathrm{~cm}$ size. The area were fertilized using Triple Super Phosphate (TSP) and Kalium Cloride (KCl) fertilizer at $75 \mathrm{~kg} / \mathrm{ha}$ during land plough and using $\mathrm{N}$ fertilizer (Urea) at $100 \mathrm{~kg} / \mathrm{ha}$ applied at two months age of plant. Treatment of population density of Gliricidia sepium (Jacq) Steud at 20, 30 and 40 plants per area of 9 $\mathrm{m}^{2}$ combined with cutting interval of $3 ; 6 ; 9$ and 12 weeks were conducted in this study. Treatments were set in factorial arrangement based on block randomized design. Variables measured were including quality of leaf, dried matter production rate and vegetative growth. Results showed that nutrient content of the leaf of Gliricidia sepium (Jacq) Steud dictated by cutting interval, and vegetative performance influenced by the interaction of population density and cutting interval. In conclusion, to sustain high dry matter leaf production and quality of Gliricidia sepium (Jacq) Steud underneath coconut plantation management should be focused on the planting and defoliation regimes.
\end{abstract}

Keywords: Cutting, coconut, density, gliricidia, quality. 


\section{INTRODUCTION}

Legume tree of Gliricidia sepium had been introduced to the farmers but planting and utilization for ruminant feed are still low. Moreover, agronomical information and defoliation management of this plant were limited, especially integrated with coconut plantation, since this commodity is highly influence the economy of North Sulawesi regency. In Indonesia, Gliricidia sepium plant was called "Gamal" plant as an abbreviation of "ganyang mati alang-alang" (killed imperata cylindrica grass), due to its capability to combat imperata cylindrica grass and other weeds by shading them.

This legume tree was categorized into the medium perennial plant. Normal growth of this plant produces 7-15 pairs of the leaflet in one compound leaf. Decomposition of Gliricidia sepium leaves was relatively fast, contributed high elements of Nitrogen and Potassium and recovered soil moisture under coconut plantation (Subramanian et al., 2005). One ton of foliage is equivalent to $16 \mathrm{~kg}$ of urea, so 1 ha of G. sepium can provide $128 \mathrm{~kg}$ of urea fertility and increase economic value of the coconuts (Solangi et al., 2010).

Limitation of high-quality feed during dried season in tropical countries including Indonesia motivated scientists to provide an alternative high-quality feed of the ruminant animals (Lukuyu et al., 2011). The Gliricidia sepium plant was promoted as Nitrogen $(\mathrm{N})$ source due to its biological ability to provide the available soil $\mathrm{N}$ by fixation process (Nygren et al., 2000; Tuwei et al., 2003) and to produce high plant biomass during dried season (Tuwei et al., 2003). The decomposition of Gliricidia sepium leaves was relatively fast and contributed green manure indicated by 1 ton of $G$. sepium leaves were equivalent with $16 \mathrm{~kg} \mathrm{~N}$ fertilizer or 1 ha produced $128 \mathrm{~kg}$ equivalent with $\mathrm{N}$ fertilizer (Solangi et al., 2010). Therefore, the G. sepium plant was categorized as the second multifunction trees after the Leucaena leucocephala tree in the tropical humid areas (Kabi and Lutakome, 2013). The G. sepium plant was also resistant to the psyllid pest (Hetero psyllacubana) and able to produce sprouts, grow vigorously and tolerant to repeated defoliation by providing green leaves in dried season.

Harvest frequency of G. sepium plant was critical management factor affecting sustainable nutrient quality and biomass production. Therefore, regulation of the accurate defoliation increased quality and total plant production of 2.0 -20 ton per ha per year (Simons and Stewart, 1994). The recommended defoliation interval of G. sepium plant was 6 to 12 weeks in tropical humid areas (Edwards et al., 2012) and nutrient value of legume trees decreased gradually following the increasing maturation (Kabi and Bareeba, 2008).

Effect of population density of the G. sepium in full sun pasture areas reduced leaf and steam dried matter production following increasing plant population from 20.000 to 40.000 trees per ha (Ella et al., 1989). Population density related to the morphological traits of G. sepium plant under coconut plantation areas had not been fully explored. The objective of this study was to evaluate quality, production and vegetative growth of $G$. sepium under different population density and defoliation frequencies underneath coconut plantation.

\section{MATERIALS AND METHODS}

\section{Experimental Site}

This study was conducted at Coconut and Other Palma Research Center (BALITKA) Manado, located $15 \mathrm{~km}$ from Manado City. This location received the rainfall average of $2700 \mathrm{~mm}$. Rainfall distribution was fairly even, except for a period of lower rainfall (100-150 mm per month) from July to September. The $\mathrm{pH}$ of the fertile, sandy loam soil was around 6. Light transmission (PAR) at the site under mature tall coconuts average was $73 \%$ at $10.00 \mathrm{am}$.

\section{Experimental Design}

G. sepium plant was planted using tree stick of $30 \mathrm{~cm}$ length with a diameter of $2-3 \mathrm{~cm}$ in the polybag of $15 \times 25 \mathrm{~cm}$ size during 8 weeks. Fertilizers of triple super phosphate (TSP) and Sodium Chloride $(\mathrm{KCl})$ with each dose of 75 $\mathrm{kg} / \mathrm{ha}$ were applied at the time of soil plough and fertilizer of $100 \mathrm{~kg} / \mathrm{ha}$ was applied 2 weeks after removing plant at the polybag to coconut plantation areas. The coconut tree distances from one another were $10 \mathrm{~cm} \times 10 \mathrm{~cm}$ at age average of 40 years old.

Treatments were arranged in a factorial pattern based on block randomized design with 3 replications (Steel and Torrie, 1981). Two factors of plant were set for population density as factor $\mathrm{A}$ and cutting interval as factor B. Factor A was 
divided into 3 treatments: 20 plants per $9 \mathrm{~m}^{2}$ area $\left(\mathrm{a}_{1}\right), 30$ plants per $9 \mathrm{~m}^{2}$ area $\left(\mathrm{a}_{2}\right)$ and 40 plants per $9 \mathrm{~m}^{2}$ area $\left(\mathrm{a}_{3}\right)$ with distances among plants as shown in Table 1. Factor B was divided into 4 treatments of different cutting interval: 3 weeks $\left(b_{1}\right), 6$ weeks $\left(b_{2}\right), 9$ weeks $\left(b_{3}\right)$ and 12 weeks $\left(b_{4}\right)$.

The experimental plots were placed $2 \mathrm{~m}$ from coconut tree to avoid root competitions of nutrients. Weeds were removed out from each plot by using a combination of two kinds of herbicides. The first one contains the active ingredient of Glifosat $480 \mathrm{~g} / \mathrm{L}$ to control grass, and the second one contains the active ingredient of 2.4-D686 $\mathrm{g} / \mathrm{L}$ useful to control broadleaves weeds. Experimental plants at each plot were trimmed or clearing cut at 12 weeks after planting to find the uniform growth. Schedule of the treatments of cutting interval were conducted (Figure 1) in the following procedures:

1. Plants of treatment $b_{4}$ at the age of 8 weeks after trimming were cut and gave the period of re-growth of 12 weeks for the next harvest.

2. Plants of treatment $b_{3}$ at the age of 11 weeks after trimming were cut and gave the period of re-growth of 9 weeks for the next harvest.

3. Plants of treatment $b_{2}$ at the age of 14 weeks after trimming were cut and gave the period of re-growth of 6 weeks for the next harvest.

4. Plants of treatment $b_{1}$ at the age of 17 weeks after trimming were cut and gave the period of re-growth of 3 weeks for the next harvest.

\section{Sampling Procedures and Measurements}

Treatments were applied at different age of re-growth after trimming; on the contrary, harvest was conducted at the same ages of the plant with different in cutting intervals. Harvests were done by cutting the tree at $100 \mathrm{~cm}$ above the ground surface. Branches were cut at $10 \mathrm{~cm}$ length from the main tree. Sampling number of leaves and trees were counted and weighed in fresh materials. Variables measured were including vegetative growth, numbers of leave, compound leaves and branches, leaves/ stem ratio, dried matter production rate, and quality of leaves including the content of dry matter (DM), crude

Table 1. Number and Distances of Plants within Rows in the Area of Experimental Units

\begin{tabular}{ccccc}
\hline $\begin{array}{c}\text { Number Plant/ Plot } \\
\left(9 \mathrm{~m}^{2}\right)\end{array}$ & $\begin{array}{c}\text { Distance between } \\
\text { rows }(\mathrm{m})\end{array}$ & $\begin{array}{c}\text { Distance within } \\
\text { rows }(\mathrm{m})\end{array}$ & Plant in wow & Row in plot \\
\hline 20 & 0.50 & 1.00 & 4 & 5 \\
30 & 0.50 & 0.67 & 6 & 5 \\
40 & 0.50 & 0.50 & 8 & 5 \\
\hline
\end{tabular}

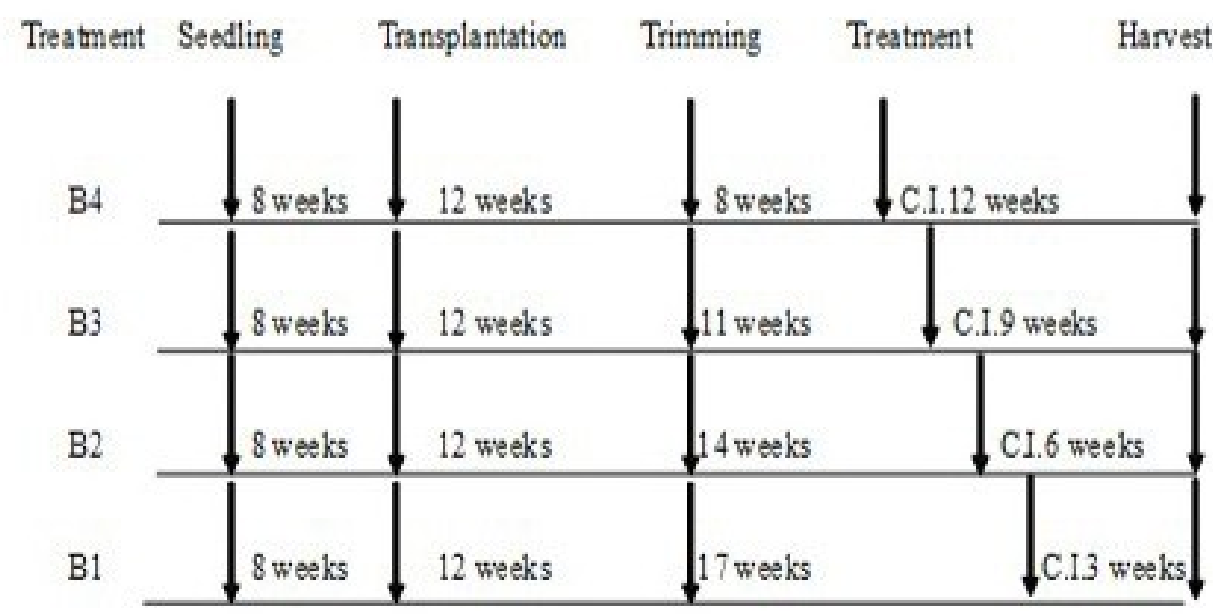

Figure 1. Time Schedule of Cutting Intervals (C.I) 
protein $(\mathrm{CP})$, neutral detergent fiber (NDF), acid detergent fiber (ADF), calcium (Ca) and phosphorus $(\mathrm{P})$.

\section{Data Analysis}

Data were analyzed by using analysis of variance and the treatment means were compared by honestly significance difference (HSD) test.

\section{RESULTS AND DISCUSSION}

\section{Leaf Quality}

Interaction of treatment did not affect significantly nutrient content of G. sepium leaves. The effects of population density (A-factor) on all variable measured is not a significant difference $(\mathrm{P}<0.05)$. On the other hand, cutting intervals (Bfactor) affect significantly on leaf chemical compositions especially on DM and CP contents (Table 2). Almost all of the parameters measured were significantly lower in the treatment of $b_{1}$ except for CP $(30.1 \%)$ and $\mathrm{P}(0.312 \%)$ contents were significantly higher than others treatments. Even though the CP contents decline along the increasing of the ages of the plants but this decreasing is not significantly difference, indicating that protein synthetics in leaves of Gliricidia sepium is still running up to the $\mathrm{b}_{4}$ treatment, as long as photosynthetic still works (Kabi and Lutakome, 2013). Decrease in CP content of $G$. sepium herbage in response to increase cutting interval is in agreement with previous observations (Edwards et al., 2012). High CP content of the leaves ranged between $220 \mathrm{~g} / \mathrm{kg} \mathrm{DM}$ to $291 \mathrm{~g} / \mathrm{kg}$ DM is an indication of the high nutritive value for the ruminant ration
(Kabi and Lutakome, 2013). High CP content in Gliricidia sepium leaf was also reported about $200 \mathrm{~g} / \mathrm{Kg}$ DM to $300 \mathrm{~g} / \mathrm{kg}$ DM (Simons and Stewart, 1994).

Dry matter content tended increase up to treatment $b_{4}$ or cutting interval at 12 weeks were significantly higher than those in treatment $b_{1}$ and $\mathrm{b}_{2}$, which this different is approximately 30 percents. This increasing might be due to different of re-growth age of plant after trimming, which is related to the duration of the plant to gain assimilation in this period. This result was in agreement with the study reported by Edwards et al. (2012) that indicated in the humid tropical areas, harvest of G. sepium should be done varies at the ages of 6 to 12 weeks to obtain the high DM production, but decreasing of production and nutritive value will occur at the old ages of plant (Kabi and Bareeba, 2008). The crude fiber content in terms of NDF and ADF, and mineral content of $\mathrm{Ca}$ and $\mathrm{P}$ were not changes up to treatment of $\mathrm{b}_{4}$ (12 weeks or 3 months). Nevertheless, the fiber content of the foliage increased following a curvilinear trend as the fodder matured to 6 months but the level of lignifications as expected increased linearly with delayed coppice re-growth harvesting (Kabi and Lutakome, 2013). Linear increase in lignifications with delayed harvest has a negative connotation to the nutritional value of the herbage. Lignin polyphenol has the ability to sequester and form ligno-cellulosic bonds with cellulose and hemicelluloses which slow down rumen microbial degradation hence impacting on quality of the herbage as feed for dairy cattle (Ikhimioya et al., 2005).

Tabel 2. Chemical Compositions of Leaves of Gliricidia sepium

\begin{tabular}{ccccc}
\hline \multirow{2}{*}{$\begin{array}{c}\text { Nutrient Content } \\
(\%)\end{array}$} & \multicolumn{4}{c}{ Cutting Intervals (weeks) } \\
\cline { 2 - 5 } & 3 & 6 & 9 & 12 \\
\hline Dry Matter & $18.42^{\mathrm{a}}$ & $20.14^{\mathrm{ab}}$ & $22.40^{\mathrm{bc}}$ & $24.66^{\mathrm{c}}$ \\
Crude Protein & $30.01^{\mathrm{b}}$ & $28.10^{\mathrm{ab}}$ & $27.17^{\mathrm{a}}$ & $26.38^{\mathrm{a}}$ \\
NDF & $44.16^{\mathrm{a}}$ & $47.72^{\mathrm{b}}$ & $48.97^{\mathrm{b}}$ & $47.96^{\mathrm{b}}$ \\
$\mathrm{ADF}$ & $23.61^{\mathrm{a}}$ & $27.72^{\mathrm{b}}$ & $27.54^{\mathrm{b}}$ & $27.27^{\mathrm{b}}$ \\
$\mathrm{Ca}$ & $1.34^{\mathrm{a}}$ & $1.72^{\mathrm{b}}$ & $1.76^{\mathrm{b}}$ & $1.88^{\mathrm{b}}$ \\
P & $0.312^{\mathrm{b}}$ & $0.253^{\mathrm{a}}$ & $0.248^{\mathrm{a}}$ & $0.244^{\mathrm{a}}$ \\
\hline
\end{tabular}

Different superscripts in the same row indicate significantly different $(\mathrm{P}<0.05)$ 


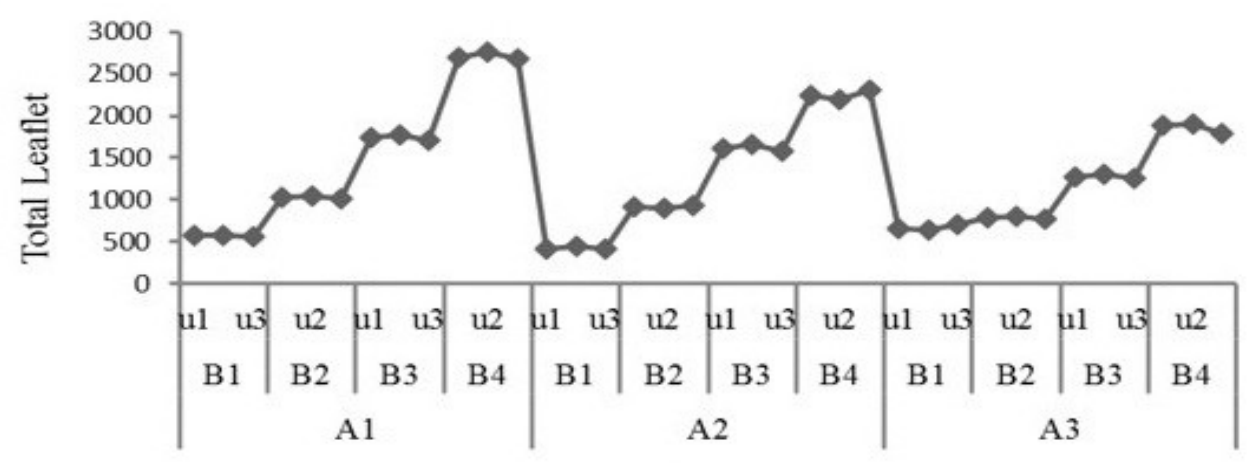

Treatment

Figure 2. Total Leaflet

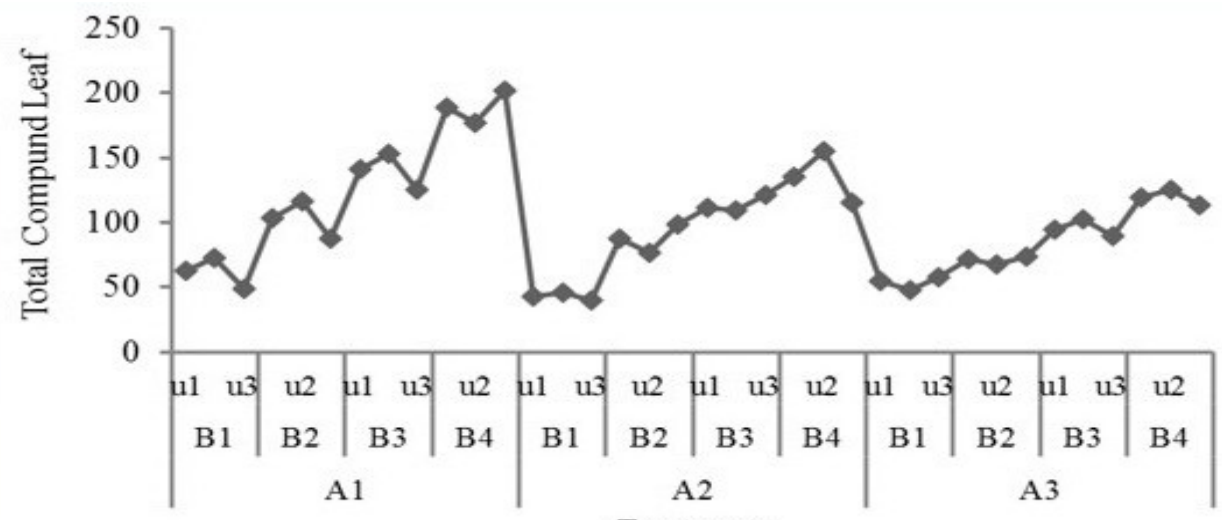

Treatment

Figure 3. Total Compound Leaf

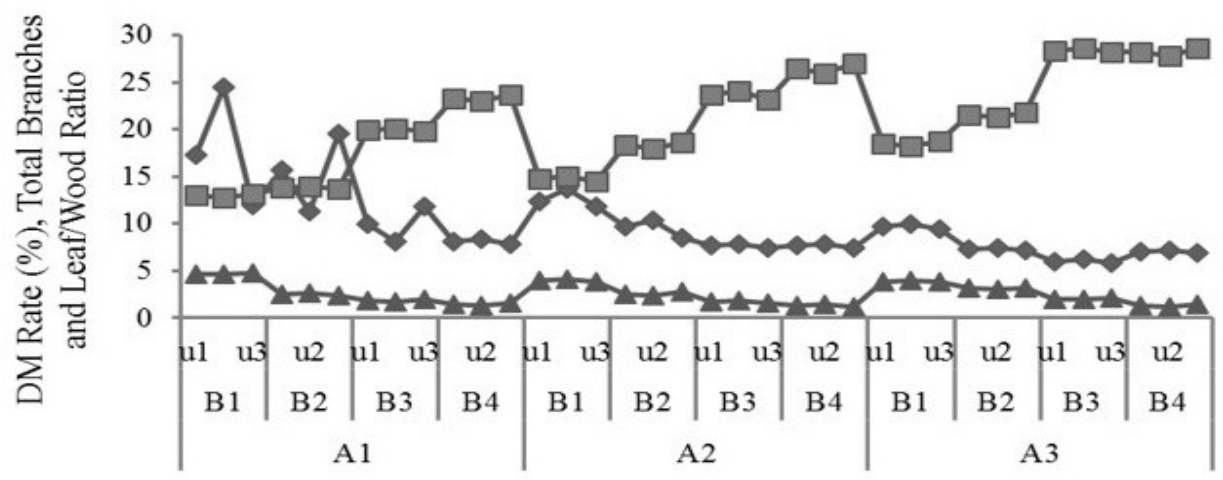

Treatment

Figure 4. Dry Matter Rate Accumulation, Total Branches and Leaf/Wood Ratio. - : DM Rate; : Total Branches; $\boldsymbol{\Delta}$ : Leaf/Wood Ratio 
Tabel 3. The Effects of Interactions on Vegetative Performance of G. sepium

\begin{tabular}{crrrrr}
\hline \multirow{2}{*}{ Interaction } & \multicolumn{5}{c}{ Variable } \\
\cline { 2 - 5 } Leaflet & Compound Leaf & No of Branches & DM rate & Ratio L/W \\
\hline a1b1 & $574.00 \pm 10.83^{\mathrm{d}}$ & $61.30 \pm 11.72^{\mathrm{d}}$ & $17.9 \pm 6.23 \mathrm{a}$ & $13.00 \pm 0.19^{\mathrm{d}}$ & $4.72 \pm 0.08^{\mathrm{a}}$ \\
a1b2 & $1024.50 \pm 17.23^{\mathrm{c}}$ & $102.00 \pm 14.36^{\mathrm{c}}$ & $15.52 \pm 4.11^{\mathrm{a}}$ & $13.84 \pm 0.16^{\mathrm{d}}$ & $2.53 \pm 0.12^{\mathrm{b}}$ \\
a1b3 & $1740.10 \pm 30.78^{\mathrm{b}}$ & $139.80 \pm 14.16^{\mathrm{b}}$ & $9.99 \pm 1.88^{\mathrm{b}}$ & $19.92 \pm 0.12^{\mathrm{c}}$ & $1.86 \pm 0.16^{\mathrm{c}}$ \\
a1b4 & $2716.80 \pm 43.16^{\mathrm{a}}$ & $189.00 \pm 12.41^{\mathrm{a}}$ & $8.08 \pm 0.27^{\mathrm{b}}$ & $23.30 \pm 0.35^{\mathrm{b}}$ & $1.46 \pm 0.11^{\mathrm{d}}$ \\
a2b1 & $429.10 \pm 21.07^{\mathrm{d}}$ & $42.90 \pm 3.00^{\mathrm{d}}$ & $12.63 \pm 0.95^{\mathrm{a}}$ & $14.72 \pm 0.28^{\mathrm{d}}$ & $3.95 \pm 0.10^{\mathrm{ab}}$ \\
a2b2 & $917.50 \pm 20.80^{\mathrm{c}}$ & $87.70 \pm 10.67^{\mathrm{c}}$ & $9.51 \pm 0.89^{\mathrm{b}}$ & $18.33 \pm 0.34^{\mathrm{c}}$ & $2.55 \pm 0.20^{\mathrm{b}}$ \\
a2b3 & $1621.20 \pm 35.13^{\mathrm{b}}$ & $114.10 \pm 6.27^{\mathrm{b}}$ & $7.66 \pm 0.21^{\mathrm{b}}$ & $23.58 \pm 0.46^{\mathrm{b}}$ & $1.72 \pm 0.12^{\mathrm{d}}$ \\
a2b4 & $2243.30 \pm 56.44^{\mathrm{a}}$ & $135.40 \pm 19.63^{\mathrm{b}}$ & $7.66 \pm 0.15^{\mathrm{b}}$ & $26.47 \pm 0.49^{\mathrm{a}}$ & $1.29 \pm 0.11^{\mathrm{d}}$ \\
a3b1 & $666.30 \pm 31.38^{\mathrm{c}}$ & $53.59 \pm 5.16^{\mathrm{d}}$ & $9.68 \pm 0.23^{\mathrm{b}}$ & $18.51 \pm 0.29^{\mathrm{c}}$ & $3.88 \pm 0.08^{\mathrm{ab}}$ \\
a3b2 & $791.00 \pm 20.27^{\mathrm{c}}$ & $70.85 \pm 2.76^{\mathrm{c}}$ & $7.34 \pm 0.16^{\mathrm{b}}$ & $21.54 \pm 0.23^{\mathrm{b}}$ & $3.15 \pm 0.06^{\mathrm{b}}$ \\
a3b3 & $1280.1 \pm 20.25^{\mathrm{b}}$ & $95.06 \pm 6.70^{\mathrm{c}}$ & $6.02 \pm 0.18^{\mathrm{c}}$ & $28.34 \pm 0.20^{\mathrm{a}}$ & $2.03 \pm 0.08^{\mathrm{c}}$ \\
a3b4 & $1863.70 \pm 58.78^{\mathrm{a}}$ & $119.20 \pm 6.30^{\mathrm{b}}$ & $7.03 \pm 0.12^{\mathrm{b}}$ & $28.16 \pm 0.37^{\mathrm{a}}$ & $1.34 \pm 0.15^{\mathrm{d}}$ \\
\hline
\end{tabular}

$\mathrm{DM}$ rate $=$ dry matter accumulation rate. $\mathrm{L} / \mathrm{W}=$ leaf/wood. Different superscripts in the same column indicate significantly different $(\mathrm{P}<0.05)$

\section{Vegetative Growth}

Vegetative growth was measured in term of leaf number, compound leaf number, branches, leaf/ stem ratio, and dried matter production rate. Results showed (Table 3) that the highest numbers of the leaflet by $2716.8 ; 2243.3$ and 1863.7 were found at the interaction of the $a_{1} b_{4} ; a_{2} b_{4}$ and $a_{3} b_{4}$ treatments. The highest number of compound leaves by 189.0 was found at the interaction $a_{1} b_{4}$. These highest numbers were related to the cutting interval of 12 weeks $\left(b_{4}\right)$ and correlated with the highest dried matter content in the cutting interval of 12 weeks. The increase of this leaf biomass might be due to the long periods of re-growth, a number of growing buds and branches, leaf area index and prolonged shoot carbohydrate reserves, all of which probably improved on photosynthetic efficiency (Larbi et al., 2000; Kabi and Lutakome, 2013).

There were two parameters showed the same rhythm of growth namely number of branches and leaf/wood ratio. The highest number of branches was found in the interaction of treatments of $a_{1} b_{1}$; $\mathrm{a}_{1} \mathrm{~b}_{2}$ and $\mathrm{a}_{2} \mathrm{~b}_{1}$ at 17.94, 15.52 and 12.63, respectively. The lowest number of branches was found in the interaction of $a_{3} b_{3}$ at 6.02. The highest leaf/wood ratio was obtained in the interaction of treatment of cutting interval of 3 weeks with plant population density of 20 plants per $9 \mathrm{~m}^{2}$, at ratio value of 4.72 (Table 3). This highest leaf/wood ratio might be affected by the age of plant still young ( 3 weeks) and low population density causing non-overlapping plants and availability space for growing buds and production of new branches. This result was not in agreement with the result reported by Kabi and Lutakome (2013) finding that the highest of leaf/stem ratio in G. sepium in Africa was obtained in the optimum cutting frequency of 8 weeks and significantly decreased at the cutting age of 16 and 24 weeks, followed by the increase of NDF. The difference of the result in this study in Indonesia and Africa might be due to the difference of the climate, especially rainfall frequencies in Indonesia and in Africa on the averages of 2,700 $\mathrm{mm}$ and $1,320 \mathrm{~mm}$ respectively. Both parameters showed tended to decrease following the delayed of cutting intervals (Figure 
4) indicating not beneficial to provide forage for the animal. This study also revealed that the highest dried matter production rate was obtained in the $\mathrm{a}_{3} \mathrm{~b}_{3}$ and $\mathrm{a}_{3} \mathrm{~b}_{4}$ treatment interactions at 28.34 and 28.16, respectively (Table 3 ).

Generally, the total leaflet and total compound leaf of G. sepium were mainly dictated by cutting interval treatment compared with plant density treatment (Figure 2 and 3). Even though, dry matter production rate was also increased following the cutting interval, on the other hand, the total branches decreased slightly following the level of population density, but the leaf/wood ratio was almost stable (Figure 4). Management of $G$. sepium by looping influence did not only produce biomass yield but also the fiber yield as well as leaf:stem ratio that greatly gave the impact on its quality (Thapa et al., 1997), except crude protein content in leaves, not affected by plant density treatment until cutting interval of 24 weeks (Kabi and Lutakome, 2013).

Crude protein content was constant due to $G$. sepium trees subjected to periodic pruning actively fix atmospheric $\mathrm{N}_{2}$. Re-nodulation and onset of $\mathrm{N}_{2}$ fixation following pruning occurred rapidly at cutting regime of 24 weeks and produced the highest amount of fixed nitrogen in aboveground biomass (Nygren et al., 2000).

\section{CONCLUSION}

It can be concluded that to sustain high dry matter leaf production and quality of Gliricidia sepium (Jacq) Steud underneath coconut plantation management, it should be focused on planting and defoliation regimes.

\section{REFERENCES}

Ella, A., C. Jacobsen, W.W. Stur and G.J. Blair. 1989. Effect of plant density and cuttingfrequency on the productivity of four tree legumes. Tropical Grassland. 23: 28-34.

Edwards, A., V. Mlambo, C.H.O Lallo, and G.W. Garcia. 2012. Yield, chemical composition andIn-vitro ruminal fermentation of leaves of L.leucocephala, G.sepium andTrichantheragigateanas influenced by harvesting frequency. J. Anim. Sci. Adv. 2: 321-331.

Ikhimioya, I., O.A. Isahl ., U.J. Ikhatua and M.A. Bakimole. 2005. Rumen degradability of dry matter and crude protein in tree leaves and crop residues of humid Nigeria. Pakistan. J. Nutr. 4(5):313-320

Kabi, F and F.B.,Bareeba. 2008. Herbage biomass production and nutritive value of mulberry(Morusalba) and Calliandra calothyrsus harvested at different cutting frequencies. Anim. Feed. Sci. Technol. 140: 178-190.

Kabi, F, and P. Lutakome. 2013. Effect of harvesting Gliricidia sepium (Jacq) Steud at different cutting frequencies on quantity and quality of herbage biomass for dairy cattle nutrition. J. Anim. Sci. Adv. 3(6):321336.

Larbi, A., A.A. Awojide, I.O. Adekunle, D.O. Ladipo, and J.A.Akinlade. 2000. Fooder production Responses to pruning height and fooder quality of some trees and shrubs in a forest- savanna transition zone in Southwestern Nigeria. Agroforestry Systems. 48:157-168.

Lukuyu, B., S. Franzel, P.M. Ongadi, and A.J. Duncan. 2011. Livestock feed resources: current Production and management practices in central and northern rift valley provinces of Kenya. Livest. Res. Rural Dev. (23) article \#5. http://www.Irrd.org/ Irrd23/5/luku23112.htm.

Nygren, P., P. Cruz, A. Domenach, V. Vaillant, and J. Sierra. 2000. Influence of forage harvesting regimes on dynamic of biological dinitrogen fixation of a tropical woody legume. Tree Physiol. 20: 41-48.

Simons, A.J., and J.L. Stewart. 1994. Gliricidias sepium - a Multi Purpose Tree Legume. In:Gutteridge, R.C and H.M. Shelton (Ed). Forage Tree Legume in Tropical Agriculture.CAB International, Wallingford UK. pp. 389.

Steel, R.G.D dan J.H. Torrie. 1981. Principles and Procedures of Statistics, a Biometrical Approach. International Student Ed. McGraw-Hill Book Company.

Subramanian, P., P. Dhanapal, and H.P. Maheswareppa. 2005. Gliricidia sepium as green manure in improving fertility and productivity of coconut under coastal littrol sandy soil. J. Plantation Crops. 33(3):179183.

Solangi, A.H., B. Mal, A.R. Kazmi, and M.Z. Iqbal. 2010. Preliminary studies of the major characteristics, agronomy feature and nutrient value of Gliricidia sepium in coconut plantations in Pakistan. Pakistan J. 
Bot. 42(2):825-832.

Thapa, B., D.H. Walker, and F.L. Sinclair. 1997. Indigenous knowledge of feeding value of tree fooder. Anim. Feed Sci. Technol. 67: 97-114.
Tuwei, P.KK., J.N. Kangara, J. Poole, F.K. Ngugi, and J.L. Stewart. 2003. Factors affecting biomass Production and nutritive value of Calliandra calothyrsusleaf as feed for ruminants. J. Agri. Sci. 141:113-127 